\title{
LEARNING STYLES AND STRATEGIES
}

\section{Zuzana Simkova}

\author{
DOI: $10.18355 /$ PG.2015.4.1.82-88
}

\begin{abstract}
In this article, I deal with learning styles and strategies of students at secondary school. I focus on Howard Gardner's distinction of seven multiple intelligences. I analyse individual students'preferences and the way how they learn foreign language. The results show the importance of empowering of all the multiple intelligences to make the educational process effective. Therefore, I proposed two activities which develop all intelligences at the same time.
\end{abstract}

\section{Key words}

learning styles, multiple intelligences, students, learning preferencies, activities

Countries around the world cooperate therefore the economic, political, cultural, sporting and technical spheres are developed. These factors also influence the sphere of education. Technological development which facilitates communication between people and their awareness brought many new opportunities and ways how to simplify the process of education in general. Nowadays knowledge of at least one or two foreign language is necessary. The process of learning foreign languages must be effective and based mainly on communication, and therefore, in this article we will analyse the importance of learning styles to facilitate the acquisition of a foreign language and the way how to make it more effective in real authentic situations.

Learning styles and strategies are relatively a new topic in Slovak educational field. Abroad there are amounts of works and researches that describe various theories of learning style. There are different views and opinions on the way how an individual learning style can be effectively developed. Different types of diagnostic tests and questionnaires were used to determine learning styles. This area is still to be explored, as well as the impact of learning styles on the effectiveness of teaching English at a vocational training school. It is especially important for those teachers who wish to teach effectively. They must choose the right type of award and tasks and create optimal conditions in the learning process. In this article we are concentrated by a theory of learning styles according to Howard Gardner to determine the learning styles, who divides them into seven basic groups. 


\section{Intelligence type}

Linguistic

Logical-mathematical

Musical

Bodily-kinaesthetic

Spatial-visual

Interpersonal

Intrapersonal

\section{Capability and perception}

words and language

logic and numbers

music, sound, rhythm

body movement control

images and space

other people's feelings

self-awareness

Nowadays we can see a spread in English teaching due to the necessity of this language in different professions as IT profession, medicine or business. Vocational English teachers due to lack of teaching materials sometimes have problems to get all the necessary materials for teaching and must often prepare their lessons by themselves without any book support.

We have to admit that it is really difficult to find a suitable material for students. Teachers must prepare the lessons for future cosmeticians, car mechanics and other professions which require special knowledge of vocabulary: How is the classic English different from teaching vocational English? What type of material to choose? What is the difference between general English teaching and teaching of English for special purposes? It is very challenging to find an appropriate material which would support all the learning styles. Professional English teachers also face the problem that even though they are great experts in the language, they needn't to have an overview of the field in which they have specialized and they can face the problem how to teach this special language to their students. The aim of this work is to explore the individual learning styles of each student and to analyse the relationship between different learning styles.

Effective learning and teaching are key skills, since there is a constant need for technology transfer and speak foreign languages, especially English. At the same time, everybody is different and has individual and special needs and requirements for learning the foreign language. It is necessary for teachers to distinguish and respect the individual learning styles of their students. So the second part of research is focused on the analysis of students' individual preferences in the process of acquiring.

\section{The research objectives}

The essential part of this experiment was to find out the learning styles of individual students and their impact on the way of acquiring the target language.

\section{The methods of research}

The questionnaire was used as a method of research. The various types of 
questions were provided to students in order to find out additional information about their learning styles. The analysis was made out of all the information gained from the students' answers.

\section{Definition of research problem}

The aim of this work was to determine the types of exercises and methods which would be the most suitable for students with individual learning styles. For this purpose I chose theory by H. Gardner. Currently, the great emphasis is placed on language skills, the amount of vocabulary and grammar knowledge. The role of teacher is to prepare such materials which will support self-knowledge of students, individual learning styles and will facilitate learning process.

I chose the secondary vocational school students for this analysis. These students know their own learning styles and ways how to learn effectively and without expending too much effort.

The work thus examines the effectiveness of teaching professional English (English for cosmeticians) in terms of learning styles. The work also analyses questions such as: Are students in a research-cut file types to only one learning style? Are the exercises suitable only for students with a given learning styles? The answers to these questions, I tried to find.

\section{Research objectives}

We set the following research objective:

1 To identify learning styles of students in the research file.

\section{Research Hypothesis}

According to the knowledge and available information, the following hypothesis was stated:

Students do not have one specific learning style. Students' learning style consists of a combination of two to three main styles.

I assume that students will have unique style of learning, because each person is a complex personality. Pupils with specific learning styles will thrive especially in this type of exercises intended and here we find the greatest continuity, but they can also thrive in other types of exercise, but to a lesser extent. I also assume that students will have more than one learning style and if so, these two or three styles will influence each other in a positive way. 
Results

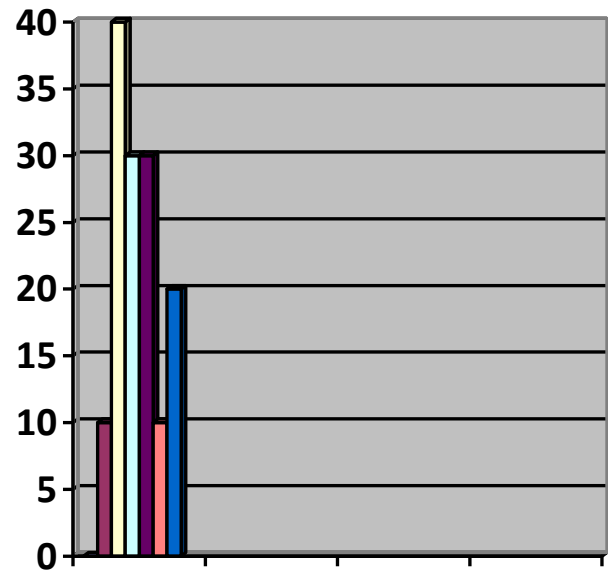

10 students

\begin{tabular}{|l|}
\hline Linguistic \\
$\square$ Logical- \\
Mathematical \\
$\square$ Musical \\
$\square$ Bodily- \\
Kinesthetic \\
$\square$ Spatial-Visual \\
$\square$ Interpersonal \\
$\square$ Intrapersonal
\end{tabular}

Figure 1 Representation of the learning styles of individual students

The following results were achieved based on the intelligence test performed according to $\mathrm{H}$. Gardner. Figure 1 confirms the hypothesis 1 because pupils prevailed 2-3 types of intelligences and learning styles. When we examine the chart closer, we find that language style is completely absent and logical mathematical and interpersonal style has only one pupil (10\%).

The results show that the largest representation has a musical learning style with $40 \%$. The same percentage is represented by Bodily-kinaesthetic and Spatial-Visual learning style $(30 \%)$. Twenty percent of students have intrapersonal learning style that prevails interpersonal style (10\%).

I prepared various types of questions to analyse individual students' styles. The results I presupposed were confirmed. I supposed that most of my students will prefer Bodily-kinaesthetic and Musical style. Students remember things much easier when they perform the tasks by themselves.

\section{The way to develop and strengthen all the learning styles}

We recommend several activities to develop all the learning strategies based on the results. It is important to remember that there's no single learning style that all children should try to use. Students' learning styles and abilities are as distinctive as their personalities. It is necessary to develop all of them because in the schools there are mixed ability students, therefore teachers have to use such activities that are appropriate, effective and efficient for all the students. Teachers should try to find some interesting, funny and at the same time educational extracurricular activities tailored to students' unique skills. They have to try to help students develop a repertoire of learning styles. Experts say the most successful students make the most of their natural 
learning styles and abilities and learn how to use other styles as well. It is helpful and important for teachers to encourage their students to strengthen learning skills other than those with which they are already comfortable and familiar with. Teachers should encourage students with kinaesthetic tendencies to act out a tune or a story or ask them to make story-telling or homework based on physical movement. Make students with auditory skills talk out loud with classmate or provide art classes for those with visual learning strengths. Those students learn more easily if they work in groups and cooperate with other students. They might listen to a book on tape and read along or play games that involve speaking and observation. Students with a visual learning style find ways to "feel" images, such as books with textures. Have them listen to a book or watch a movie. Learning styles differ from student to student and therefore in our paper we will also propose and analyse two activities which could be used during the lesson to cover more than two learning styles.

The first very complex activity is drama. This type of activity is tailored to meet the objectives to develop and strengthen all the learning styles. It is a complex activity which focuses on the empowering listening, reading, writing skills. Within drama activity we develop all three Bloom's domains of learning:

1. Cognitive domain: mental skills (knowledge)

2. Affective domain: growth in feelings or emotional areas (attitude or self)

3. Psychomotor domain: manual or physical skills (skills).

The cognitive domain involves knowledge and the development of intellectual skills. The affective domain (Krathwohl, Bloom, Masia, 1973) includes the manner in which we deal with things emotionally, such as feelings, values, appreciation, enthusiasms, motivations, and attitudes. The psychomotor domain (Simpson, 1972) includes physical movement, coordination, and use of the motor-skill areas.

The time needed for this activity is approximately from 30 to 45 minutes. Teacher states the topic of the performance. He pre-teaches students the vocabulary necessary for performing. He can play the short scene of the performance at the beginning. This activity can be done without listening to the short scene. Teacher can play scene without sound and the students' task will be to dub the scene and perform as well. After that students work in small groups and prepare their version of the play. In this way, stronger students help weaker ones, they learn vocabulary, they cooperate, they listen to each other and they are physically involved in the lesson. This activity includes all the components necessary to enhance all the learning styles.

The second activity suitable for complex development of learning styles is using music.

Using a popular song during the lesson is very effective way how to teach children. Teachers have possibility to prepare an amount of songs that are popular nowadays. The time necessary for this activity is approximately 35 minutes. Teacher plays a song video without lyrics. After the first listening, 
teacher provides students the worksheets with various activities. One of them is fill in the gap activity. Students listen to the song for the second time and they try to fill the blanks. The third listening includes checking if students filled the blanks correctly. After the third listening, students do follow up activities which are based on the song. Students practice grammar, writing and creativity within these exercises. At the end of the lesson, students can sing a song with gestures and do exercise type activities which require running and jumping. The combination of cognitive and physical involvement is the best one for effective teaching and learning.

To sum up, both activities which we mentioned above, develop more than two learning styles therefore they are really appropriate and useful and are tailored to achieve the development of individual students' needs.

\section{Bibliography}

ANTHONY, L. 1997. English for Specific Purposes: What does it mean? Why is it different? On-CUE. Vol. 5. No. 3. pp. 9-10.

BIROVA, J. 2006. Ustny prejav na hodinach cudzieho jazyka: komplexna synteza komunikativnych technik. In: Interkulturne dimenzie vo vyucovani cudzich jazykov. Nitra: FF UKF. pp.29-34.

BIROVA, J. 2013. About Theoretical Definitions of Pluralistic and Pluricultural Approaches. In: XLinguae, Vol. 6. Issue 2. ISSN 1337-8384.

BROWN, G. - YULE, G. 1999. Teaching the Spoken Language: An approach based on the analysis of conversational English. Cambridge: Cambridge University Press. ISBN 0-521-27384-6.

COHEN, A. 1998. Strategies in Learning and Using a Second Language. London: Longman. ISBN 0-582-30588-8.

DUDLEY-EVANS, T. 1998. Developments in ESP: A multi-disciplinary approach. Cambridge: Cambridge University Press.

GARDNER, H.1993. Frames of mind. The Theory of Multiple Intelligences. New York: Fontana Press. ISBN10: 0465025099.

HARMER, J. 2009. How to teach English. Harlow: Pearson Education Limited. ISBN 978-1-4058-4774-2.

HORVATHOVA. B. 2011. Rozvoj kompetencií autonómneho študenta vo vyučovaní odborného jazyka pomocou e-learningu (Development of competences of the autonomous student in professional language teaching through e-learning). Xlinguae.eu / A Trimestrial European Scientific Language Review. Issue 1 January 2011Nitra. ISSN 1337-8384.

HUCEKOVA, D. 2012. Styly a strategie ucenia. Available online: www.pppknm.sk/data/pdf/materialy/specificke_poruchy/styly_a_strategie_uc enia.pdf

HORVATHOVA, B. - REID, E.: Parents' Reflections on the Education of Gifted Children in Slovakia. In: Xlinguae, Vol. 6. Issue 1. January 2014 ISSN 1337-8384.

HVOZDIKOVA. S. 2011. Modern Teacher of English Xlinguae.eu / A Trimestrial European Scientific Language Review Issue 1 January 2011Nitra. ISSN 1337-8384. 
JECHOVA, L. 2011. How to Teach Foreign Cultures and Languages Today XLinguae.eu/ A Trimestrial European Scientific Language Review Issue 1 January 2011 Nitra, January 2011, ISSN 1337-8384.

KRASHEN, S. D. 1982. Principles and Practice in Second Language Acquisition. Oxford: Pergamon Press. ISBN 0-08-028628-3.

KRATHWOHL, D.R. - BLOOM, B.S. - MASIA, B.B. 1973. Taxonomy of Educational Objectives, the Classification of Educational Goals. Handbook II: Affective Domain. New York: David McKay Co., Inc.

LOJOVA, G. - VLCKOVA, K. 2011. Styly a strategie uceni ve vyuce cizich jazyku. Praha: Portal, s.r.o. ISBN 978-80-7367-876-0.

MURPHEY, T.1992. Music and Songs. Oxford University Press, 1992. ISBN 019437055.

POKRIVCAKOVA, S. a kol. 2008. Inovacie a trendy vo vyucovani cudzich jazykov u ziakov mladsieho skolskeho veku. Nitra: Univerzita Konstantina Filozofa. ISBN 978-80-8094-417-9.

POKRIVCAKOVA, S. a kol. 2009. Cudzie jazyky a kultury v modernej skole. Brno: Masarykova univerzita. ISBN 978-80-210-4974-1.

POKRIVCAKOVA, S. 2011. Current Issues in Teaching Foreign Languages. Brno: Masarykova univerzita. ISBN 978-80-210-5608-4.

SIMPSON, E.J. 1972. The Classification of Educational Objectives in the Psychomotor Domain. Washington DC: Gryphon House.

WALDNEROVA, J. 2014. Cultural Aspect of Communicative Behaviour (Culture-Communicational Correlations). In: XLinguae, Vol. 7. Issue 2. April 2014. ISSN 1337-8384.

WOODWARD, J. 2002. Timesaver Vocabulary Activites. (Preintermediate/intermediate). Ashford Colour Press. ISBN 1-900702-64-9.

Mgr. Zuzana Šimková

Constantine the Philosopher University

Faculty of Pedagogy

Department of Language Pedagogy and Intercultural Studies

Dražovská 4, Nitra

Slovakia

zuzana.simkova@ukf.sk 